\title{
Beyond the China Seas
}

Will China Become a Global "Sea Power"?

\section{Alexandre Sheldon-Duplaix}

\section{(2) OpenEdition}

\section{Journals}

Electronic version

URL: http://journals.openedition.org/chinaperspectives/7041

DOI: 10.4000/chinaperspectives.7041

ISSN: 1996-4617

\section{Publisher}

Centre d'étude français sur la Chine contemporaine

\section{Printed version}

Date of publication: 1 September 2016

Number of pages: $43-52$

ISSN: 2070-3449

\section{Electronic reference}

Alexandre Sheldon-Duplaix, «Beyond the China Seas », China Perspectives [Online], 2016/3 | 2016,

Online since 01 September 2017, connection on 28 October 2019. URL : http://

journals.openedition.org/chinaperspectives/7041 ; DOI : 10.4000/chinaperspectives.7041

(C) All rights reserved 


\title{
Beyond the China Seas
}

\author{
Will China Become a Global "Sea Power"?
}

\section{ALEXANDRE SHELDON-DUPLAIX}

\begin{abstract}
In May 2015, the Information Office of the State Council published a new white paper on China's military strategy stating that "overseas interests [had become] an imminent issue." Accordingly, China has embarked on a build-up aimed at making itself into a "sea power," mainly in the Indo-Pacific region, in order to deter a US intervention in Taiwan and to protect its trade in the Indian Ocean. China has acquired a medium-sized aircraft carrier with a tenth of the capability of a US super-carrier and is learning the ropes as fast as the more experienced and poorer Russia did in the early 1990s. As a source of pride to its citizens, China's aircraft carrier program plays into the hands of the Communist Party to demonstrate its legitimacy and success. And yet, China has not yet tried to challenge the superiority of the US Navy on the "far seas." With three or four carriers, China will remain a regional navy with global reach leading India, the UK, and France at that level.
\end{abstract}

KEYWORDS: Chinese Navy, sea power, overseas interests, military base abroad, "21st Century Maritime Silk Road," "string of pearls."

n May 2015, the Information Office of the State Council published a new white paper on China's military strategy stating that "overseas interests [had become] an imminent issue." The paper underlined that:

With the growth of China's national interests (Zhongguo de guojia liyi 中国的国家利益), its national security is more vulnerable to international and regional turmoil, terrorism, piracy, serious natural disasters, and epidemics, and the security of overseas interests concerning energy and resources, strategic sea lines of communication [SLOCs], as well as institutions, personnel, and assets abroad, has become an imminent issue. (1)

The paper further indicated that "(...) in response to the new demands resulting from the country's growing strategic interests, the armed forces will actively participate in both regional and international security cooperation and effectively secure China's overseas interests." Accordingly, and departing from its ideological policy of not having military bases abroad, China in December 2015 signed a comprehensive agreement with Djibouti to build a logistics facility for its anti-piracy task force in Obock. (2) In November, Chinese media quoted by South African news reports suggested that China might also build a base in Namibia to protect its interests on Africa's western coast. ${ }^{(3)}$

Since 2013, China has promoted a "21 $1{ }^{\text {st }}$ Century Maritime Silk Road" (21 shiji haishang sichou zhilu 21 世纪海上丝绸之路) that encourages investment in port infrastructure along its maritime route to Europe, suggesting to some American, Indian, and Japanese analysts the materialisation of a "string of pearls" (zhenzhu lian 珍珠链) that would allow China to construct a network of naval facilities around the Indian Ocean under the cover of commercial ventures.

Few countries can claim to be global sea powers with navies deployed and interacting around the globe. They include the United States, Britain, Russia, and France. Is China adopting a "blue water strategy" (lanshui zhanlüe 蓝水战略) to become a global sea power? And for what purpose?

\section{Precedent and binding statements}

With China's permanent deployment of three vessels in the Gulf of Aden since December 2008 and its hyperactive naval diplomacy, the People's Liberation Army Navy's (PLAN) current out-of-area deployments probably approach 2,000 ship-days for out-of-area operations. At first glance, the current situation of the PLAN appears similar to that of the Soviet Navy in 1964, when Moscow started to deploy its forces worldwide after practicing active naval diplomacy in the aftermath of Stalin's death to reassure the West. Both countries vowed never to seek foreign bases, seen as contrary to anti-imperialistic ideology. Both navies were born as coastal defence forces, progressively expanding their areas of operation thanks to large auxiliary vessels that initially made up for the lack of foreign bases. Soviet outof-area operations grew to about 4,000 ship-days in 1964 following Moscow's display of naval impotence during the Cuban missile crisis. But solving their lack of overseas bases required shifting to a policy that contradicted the political declaration that the USSR did not seek military ports in foreign countries because it did not threaten anyone. This premise was conveniently set aside when the Soviet Navy gained access to foreign ports in Syria, Guinea, Algeria, Libya, and later Vietnam. But as the former commander-in-chief of the Northern Fleet, Admiral Ivan Kapitanets, explained in his book on naval strategy, the Soviet Navy never had the ports it needed:

The most difficult task for the Soviet Navy was to create a system of bases. The USSR had no bases overseas. Floating workshops and auxiliary ships could not resolve this problem. Through diplomatic channels, the USSR got permission to enter the ports of Syria, Egypt

1. The State Council Information Office of the People's Republic of China, "China's Military Strategy" (Part I), published in China Daily, 26 May 2015, www.chinadaily.com.cn/china/2015-05/26/content_20820628.htm (accessed on 27 January 2016).

2. "Foreign Minister: China to Build Navy Base in Djibouti," Agence France-Presse, 4 December 2015.

3. "Chinese naval base for Walvis Bay," South Africa Today News, 22 November 2014, http://southafricatoday.net/africa-news/southern-africa/namibia/chinese-naval-base-for-walvisbay (accessed on 27 August 2016). 
(1967), Algeria (1969, renewed in 1978), and Cuba (1970). In 1971, at the request of the Guinean government, the USSR was granted access to the port of Conakry. In 1972, Soviet ships began to enter the ports of Somalia, and in 1977 those of Benin. In 1978, they were granted access to the ports of São Tomé and Príncipe. In 1979, Vietnam granted permission to use the naval base of Cam Ranh (...). (4)

Albeit limited, those naval facilities helped the Soviet Union increase its overseas deployments. By 1976, Soviet out-of-area operations had risen to 48,000 ship-days: can we expect China to follow the same path?

In its April 2013 white paper on the "Diversified Employment of China's Armed Forces," China committed itself very strongly "never [to] seek hegemony or behave in a hegemonic manner, nor [to] engage in military expansion," opposing "any form of "hegemonism" or power politics" and vowing not to "interfere in the internal affairs of other countries." (5) In May 2015, the follow-up white paper explicitly restated those principles:

China will unswervingly follow the path of peaceful development, pursue an independent foreign policy of peace and a national defence policy that is defensive in nature, oppose "hegemonism" and power politics in all forms, and will never seek hegemony or expansion. China's armed forces will remain a staunch force in maintaining world peace. ${ }^{(6)}$

Denouncing the United States, Britain, and France without naming them, Navy Captain Zhang Junshe of the Marine Research Centre, a think tank working with the naval staff, stressed that "China had not been part of any war or armed conflict since the mid-1980s, as opposed to some countries that wage wars worldwide under the pretext of humanitarianism and democracy." (7) Directly stigmatising Washington's Iraq War and its geopolitical effects, Zhang denounced the "China threat theory" as "groundless," "for we know which country is actually disturbing the world order and unsettling certain regions." (8)

At the same time, China admits to building up its forces. The May 2015 military strategy states:

Building a strong national defense and powerful armed forces is a strategic task of China's modernization drive and a security guarantee for China's peaceful development. (...) It is a Chinese Dream of achieving the great rejuvenation of the Chinese nation. The Chinese Dream is to make the country strong. China's armed forces take their dream of making the military strong as part of the Chinese Dream. Without a strong military, a country can be neither safe nor strong. ${ }^{(9)}$

In the same document China also admits "to building itself into a maritime power":

The seas and oceans bear on the enduring peace, lasting stability and sustainable development of China. The traditional mentality that land outweighs sea must be abandoned, and great importance has to be attached to managing the seas and oceans and protecting maritime rights and interests. It is necessary for China to develop a modern maritime military force structure commensurate with its national security and development interests, safeguard its national sovereignty and maritime rights and interests, protect the security of strategic SLOCs and overseas interests, and participate in international maritime cooperation, so as to provide strategic support for building itself into a maritime power. ${ }^{(10)}$

\section{Assessing the build-up}

Western and Taiwanese experts have had a tendency to underestimate Chinese military and naval developments. The most prominent watchers and think tanks failed inexplicably and stubbornly to admit the very visible fact that the Dalian shipyard was completing the former Soviet aircraft carrier Varyag, ${ }^{(11)}$ commissioned into the PLAN in September 2012. It did not fit the views that China was putting the emphasis on its submarine forces. Few foresaw the spectacular quantitative and qualitative progress in Chinese platforms and weapon systems during the last decade, (12) including the realisation of a stealth fighter (J-20) - still dismissed by some on the day of its maiden flight. ${ }^{(13)}$ However, through the careful study of Chinese open sources, American experts revealed the operational deployment of a revolutionary weapon, the DF-21D anti-ship ballistic missile (ASBM). ${ }^{(14)}$ The space event tracking ship Yuanwang-4, received attention from Chinese netizens for its alleged involvement in an anti-ship ballistic missile test in 2011. Following a collision and a fire, the ship was moved to the Chengxi Shipyard in early 2010. Photographed in Lushun in 2011 with deflectors directed towards the skies, the ship is said to have been hit later that year by a DF-21D before being sold for scrap. (15)

Those achievements were completed before the peering eyes of Chinese netizens and publicised on the Internet prior to any official announcements, nourishing accusations by Japan and the United States of a lack of transparency. This criticism is certainly valid for the procurement of the former Varyag and other hidden programs, following a traditional culture of secrecy. But it is contradicted by the availability of Chinese Internet sources that revealed the Varyag's transformation and of more than 50 Chinese military journals, including 10 on naval affairs and technology. China has begun publishing a new magazine for foreign attachés - China Armed Forces - that matches its Western equivalents, and it has updated its official military websites and improved its biannual white papers on

4. Ivan M. Kapitanets, Flot, V Voinas tchetchogo pokolenia (The navy in the wars of the sixth generation), Moscow, Betche, 2006, pp. 160-161.

5. Information Office of the State Council, "The Diversified Employment of China's Armed Forces," The People's Republic of China, Beijing, April 2013.

6. The State Council Information Office of the People's Republic of China, "China's Military Strategy," art. cit. (Preface).

7. Wang Xiaoxuan, "Strong Navy Protects Interests," China Daily, 9 January 2012, www.chinadaily. com.cn/cndy/2012-01/09/content_14402732.htm (accessed on 27 January 2016).

8. Ibid.

9. The State Council Information Office of the People's Republic of China, "China's Military Strategy," art. cit. (Preface and Part II).

10. Ibid. (Part IV).

11. After having ignored the Varyag in its previous editions, the 2006 US Department of Defense (DoD) report stated: "Given the difficulty and expense in overhauling the ex-Varyag, it is possible, but doubtful..." See Office of the Secretary of Defense (United States), Department of Defense (DoD), "Annual Report to Congress, Military and Security Developments Involving the People's Republic of China," 2006.

12. The 2001 DoD Annual Report to Congress was not anticipating a new destroyer before 2010; both the Type 039B Yuan SSK and Type 032 Qing class SSB submarines apparently came as a surprise.

13. The fifth-generation aircraft is not mentioned in the 2009 US DoD report.

14. Andrew S. Erikson, David D. Yang, "On the Verge of a Game-Changer," United States Naval Institute Proceedings, September 2009, p. 135.

15. Discussion on the forum of China Defense.com, www.china-defense.com (accessed on 20 January 2016). 
defence. Using openly available Chinese data, the Swedish Stockholm International Peace Research Institute (SIPRI) has been able to produce its own revised estimate of China's military budget. Furthermore, it is hard to criticise China's opacity when at the same time, the United States has been hiding the development of secret weapons behind "black budgets." More recently, China has restrained its Internet enthusiasts, and less military information may be available. Ideally, China should take Japan's Defense Yearbook as a model for the detailed information it provides on the Japan Self Defense Forces' future procurements. ${ }^{(16)}$

In effect, China has embarked on an unprecedented naval shipbuilding effort since the completion of its first classes of destroyers, frigates, and submarines during the 1960-70s. Back in 2002, the US Department of Defense stated:

If China were to shift to a broader "sea control" strategy, the primary indicators would include: development of an aircraft carrier, development of robust anti-submarine warfare capabilities, development of a true area anti-air warfare capability, acquisition of large numbers of nuclear attack submarines, development of effective maritime C4ISR, and increased open water training (...). (17)

Fourteen years later, China appears to be following the very path that the US DoD sketched as an indicator of a shift towards a "broader sea control strategy." Chinese commentators are now admitting that aircraft carriers and nuclear submarines are the two pillars of the Navy "like the two wheels of a car or the two wings of a bird" (che zhi shuang lun, niao zhi shuangyi 车之双轮, 乌之双翼). ${ }^{(18)}$

During those 14 years, China has completed its first aircraft carrier, commissioned in September 2012, and has built its second generation nuclear submarines, although economic and technical constraints have restricted the production of nuclear submarines to one unit every two years. Since 2002, the PLAN has only procured four nuclear strategic submarines (SSBN) Type 09-IV Jin, (19) two nuclear attack submarines (SSN) Type 09III Shang, ${ }^{(20)}$ with four cruise missile variants (SSGN) Type 09-IIIG nearing completion to supplement the three original Type 09-I Han (SSN) and the lone Type 09-II Xia (SSBN) still in service. (21) The first strategic patrol is yet to be reported, and the small number of attack submarines is inadequate for conducting long-range operations against the United States' sea lines of communication. Alongside 70 or so conventional submarines, including 14 Air Independent Propulsion (Type 039A), (22) China's nuclear submarines can delay carrier groups steaming to the rescue of Taiwan. Furthermore, China has completed 45 major surface combatants: 22 destroyers - including 20 fitted with long-range air defence missiles and 18 equipped with two variants of a Chinese designed phased array radar "Sea Star" as well as the HQ-9 air defence missile (Type 052C/D) - and 23 missile frigates (Type 054/054A), including 21 fitted with the medium-range HQ16 air defence missile. Most of those platforms are apparently equipped with towed arrays that give them a previously non-existent anti-submarine warfare capability. China's four trial ships have played a significant role in the development of shipborne weapons. The two 6000-ton Dahua class 891 Bi Sheng (1997) and 892 Hua Luogeng (2008) trial platforms have revealed future indigenous sensors and weapons. The 891 has tested both versions of the "Sea Star" phased array radar for the 052C/D destroyers as well as the HQ-9/HQ-16 air defence missiles and YJ-62 and YJ-18 antiship missiles. The 892 currently mounts two new radars, two replicas of the US-German air defence RAM missile system, and the cruise missile
CJ-10, suggesting a land attack capability for the PLAN. Confirming its blue water ambitions, the PLAN has also procured eight 20,000-ton (Type 903) supply ships and is building the first of a class of 45,000-ton (Type 901) combat support ship, more than quadrupling its replenishment capacities for oceanic deployments. ${ }^{(23)}$

Ignoring the obsolescent missile destroyers and frigates still in service, (24) the 45 PLAN post-2002 major surface combatants match the US Pacific Fleet's cruisers and destroyers and the Japanese surface fleet, but not the combination of the two. It also outnumbers the Russian Pacific fleet (seven major combatants) as well as the entire Russian surface fleet (29 major combatants). The Russian Navy retains it superiority - albeit much eroded for its nuclear submarine fleet (13 SSBN, 8 SSGN, 19 SSN). (25) Yet, the Chinese Navy cannot compare with the Soviet Navy of 1990 with its four aircraft carriers, two helicopter carriers, and 115 missile cruisers, destroyers, and frigates supplemented by 175 gun cruisers, destroyers, and frigates, 63 nuclear strategic submarines, 52 nuclear cruise missile submarines, and 85 nuclear attack submarines. (26) Nonetheless, Western, Japanese, and Indian experts are now soberly concerned with the Chinese Navy's build-up. (27) Despite its impressive modernisation, the PLAN remains significantly weaker than the combination of the US Pacific Fleet, Taiwanese, Japanese, and Australian navies that would be involved in a Taiwan crisis scenario. The PLAN is therefore likely to pursue its build-up with, in particular, new classes of cruise missile nuclear attack submarines (Type 093G and 095) and future cruisers (Type 055) to escort its future carrier battle groups. Those developments will in turn reinforce the perception of China's assertiveness and further fuel an ongoing regional arms race.

\section{Explaining the build-up}

China's current naval developments result from the implementation of General/Admiral Liu Huaqing's 1985 strategic vision for an "offshore defense" within the "first island chain" (yidaolian yinei 一岛链以内) at first, and then to the second island chain. Linking the Kuril Islands, the Japanese Archipelago, Ryukyu Islands, Taiwan, the northern Philippines, and Borneo, the first island chain harbours US bases that restrict China's access to the Pacific. In his memoirs, Liu Huaqing wrote:

16. Ministry of Defense of Japan (MOD), "Defense of Japan 2015," www.mod.go.jp/e/publ/ W_paper/2015.html (accessed on 20 January 2016).

17. Office of the Secretary of Defense (United States), Department of Defense (DoD), "Annual Report to Congress, Military and Security Developments Involving the People's Republic of China," 2002.

18. "Cao Weidong: Zhongguo haijun zhanlüe bianhua; cong huangshui zou xiang lanshui" (Cao Weidong: Chinese naval strategy: Change from brown to blue water), Feiyangwang, 26 January 2016, http://m.fei123.com/1250000/1249269.shtm (accessed on 30 January 2016).

19. The core of nuclear deterrence, the nuclear-propelled strategic submarine (SSBN) is armed with intercontinental ballistic missiles fitted with nuclear warheads.

20. A nuclear propelled attack submarine (SSN, SSGN) is a fast platform that can stay submerged for an unlimited time and attack enemy naval forces and infrastructure at very long distances with conventional torpedoes and missiles.

21. Stephen Saunders, Jane's Fighting Ships 2015-16, Coulsdon, IHS, 2015, pp. 128-134.

22. A conventional or diesel-electric submarine is much slower than a nuclear attack submarine and must return to the surface to recharge its batteries; the air-independent variant can stay submerged for one or two weeks at a low speed.

23. Stephen Saunders, Jane's Fighting Ships 2015-16, op. cit., pp. 127-170.

24. 2 Type 052 Luhu, 4 Type 051 Luda destroyers, 12 Type 053 Jiangwei, 17 Type 053 Jianghu frigates. Ibid., pp. 136-145.

25. Ibid., p. 127.

26. Richard Sharpe, Jane's Fighting Ships, 1989-90, Coulsdon, HIS, 1989, p. 556

27. Ronald O'Rourke, China Naval Modernization: Implications for U.S. Navy Capabilities - Background and Issues for Congress, CRS Report, 23 November 2015. 
Chairman Deng reminded us that the navy had no conception of its strategic role and we had to give it a strategic direction (...). The operational area for the navy would extend to the first island chain. When our naval forces become stronger, we will cross into the northern Pacific and move towards the "second island chain" formed by the US-controlled Marianas. ${ }^{(28)}$

Cao Weidong, a researcher with the Chinese Navy's Academic Research Institute, explains how the 1985 change of strategy from "coastal defense" (jin'an fangyu 近岸防御) to "offshore defense" (jinhai fangyu 近海防御) coincided with the United Nations Convention on the Law of the Sea and with the Falklands War. The latter demonstrated that a coastal defence strategy cannot defeat a force projection navy:

The Argentines lost the Falklands on their doorstep while the British recaptured the Falklands, thousands of nautical miles from home. The lesson for the [Chinese] state was that coastal defense cannot allow you to compete for command of the sea; you have to fight for air supremacy; you must be able to fight far away from home; you need to integrate offshore operations. With those lessons, the Chinese Navy departed from its old coastal defense strategy (...). (29)

Up to the commissioning of the first air defence destroyers armed with long-range missiles in the last decade, Chinese naval vessels could not defend themselves beyond the 200 nautical miles covered by land-based naval aviation. Since then, new Chinese platforms have given the PLAN the ability to operate within the 500-1,000 nautical miles' radius beyond the first island chain. Following Liu Huaqing's steps, a majority of Chinese commentators focus on the Western Pacific in the context of a so-called "anti-access, area denial" (A2/AD), in American terminology, against a possible US intervention in support of Taiwan or Japan. The attempt to procure carrier-borne air power came as early as 1946, when Chiang Kai-shek's China made an unsuccessful attempt to acquire escort carriers in the United States to accompany its Japanese spoils and its former British cruiser. Three decades later, Beijing's strategic partnership with the West brought discussions with the United Kingdom over the purchase of Harrier VSTOL aircraft that could be used from a small carrier. This never happened. But the present carrier development seems to have originated with Liu Huaquing's visit on board the American aircraft carrier USS Kitty Hawk in May 1980: Liu was "deeply impressed by its imposing magnificence and modern fighting capacity" and immediately advocated the development of aircraft carriers to the PLA General Staff. According to Liu, justification for aircraft carriers found a rationale in the Taiwanese puzzle. Liu Huaqing's initial intention was to use an aircraft carrier against Taiwan and to protect ships operating outside the radius of land-based naval aviation:

(...) when we were focusing on the Taiwan Strait issue [1994] we realized that using land-based aviation was a waste because we would increasingly need more planes and more air bases. And if we developed an aircraft carrier, we would not need to increase the total number of planes. We would just need to modify them (...). The aircraft carrier would become a force multiplier, augmenting the fire power of the whole force. ${ }^{(30)}$

Western analysts have tended to dispute this view, arguing that a Chinese carrier would constitute too big a target. Explaining that the first justification for the aircraft carrier was air defence in the Taiwan Strait or in the South China Sea within the first island chain, Phoenix TV - a mainstream TV channel closely related to the authorities - retraced the important steps taken by Liu Huaqing when he headed the Navy (1982-87) and then the Central Military Commission (1987-98). In 1987, the Navy selected a number of outstanding young pilots and trained them to be surface ship commanders. Currently, 70\% of those pilots have served as missile frigate commanding officers and the remainder as executive officers. The aircraft carrier project was initiated under Liu Huaqing during the 1980s with the purchase of the former Australian carrier Melbourne and the design of a pre-study. (31) On 14 March 1993, North Sea Fleet Political Commissar Zhang Haiyun first revealed at a CPPCC (Chinese People's Political Consultative Conference) meeting that the Navy was working on a carrier design. ${ }^{(32)}$ For a long time, Western analysts held the view that the carrier program had been postponed or cancelled in favour of the submarine program. While Jiang Zemin was said to have opposed the carrier, it now appears that the latter was aimed at providing air defence to the naval forces deployed across the first island chain beyond the protection of land-based aviation. According to Phoenix TV, the 199596 cross-strait crisis prompted the decision by the Central Committee to accelerate the carrier program under the code name "Nine Five" (jiu wu 九五). (33)

China's secrecy on its carrier program may have been justified by a desire to avoid panicking its neighbours while waiting for Japan and South Korea to commission their large helicopter carriers. ${ }^{(34)}$ In January 2012, China Daily commentated on the three trial runs of the former Varyag, China's first aircraft carrier, as "a milestone in the Chinese navy's development." At the same time, the paper dismissed "the sharp reactions from some countries" and their "intent on raising false alarms." Putting the emphasis on home defence and sovereignty disputes, the paper cited "a coastline of 18,000 kilometers, more than 6,500 islands, and about 3 million square kilometers of maritime area" as a prime justification for China to develop "a strong and modern navy to prevent any violation of its territory, sovereignty over the islands and maritime interests in its waters." (35)

Deprived of catapults like its Russian sister-ship Admiral Kuznetsov, China's first aircraft carrier cannot compare with American and even French aircraft carriers because its aircraft use a ski jump and consume more fuel to take off. As a consequence, they cannot carry a heavy payload of bombs for strike missions but are powerful enough to mount air-to-surface missiles. Acting as an air defence platform, an aircraft carrier in the South China Sea would neutralise the territorial claims of China's small neighbours on the Spratly

28. Liu Huaqing, Liu Huaqing huiyi lu (Memoirs of Liu Huaqing), Beijing, Zhongguo renmin jiefangjun chubanshe, 2004.

29. "Cao Weidong: Zhongguo haijun zhanlüe bianhua; cong huangshui zou xiang lanshui" (Cao Weidong: Chinese naval strategy: Change from brown to blue water), art. cit.

30. Liu Huaqing, Liu Huaqing huiyi lu (Memoirs of Liu Huaqing), op. cit.

31. Alexandre Sheldon-Duplaix, "Chinese Aircraft Carriers: They're Already on the Way," China Analysis, No. 3, January-February 2006.

32. "Junqing guancha: haiquan zhanlüe cuisheng Zhongguo hangkong mujian (zutu)" (Military observation: The birth of the Chinese aircraft carrier sea power strategy [Photos]), Feiyangwang, 26 January 2016, http://m.fei123.com/1250000/1249244.shtml (accessed on 15 January 2016).

33. Ibid.

34. "Zhongguo weihe gaodiao puguang 'Waliangge' hangmu jiqi xiangguan gongcheng" (Why such a lack of discretion around the refurbishing of the aircraft carrier Varyag?), Milchina.com, 26 May 2010, www.milchina.com/2010/0526/2133.htm (accessed on 15 January 2016); Alexandre Sheldon-Duplaix, "Chinese Aircraft Carriers: They're Already on the Way," art. cit.

35. Wang Xiaoxuan, "Strong Navy Protects Interests," art. cit. 
islands and answer President Hu Jintao's November 2003 call for strengthening the system to defend the country's sea rights and interests. ${ }^{(36)}$ Both President $\mathrm{Hu}$ Jintao and Prime Minister Wen Jiabao attended the commissioning ceremony for the Liaoning in September 2012, followed two months later by the first successful carrier landing of a J-15 Black Shark, the Chinese unlicensed variant of the Soviet Su-33 Flanker naval fighter. As of January 2016, the Chinese Navy appears to be doing as well as Russia in the early 1990s. As of January 2016, it operated ten confirmed J-15 fighter-bombers on the Liaoning, about one third of the air group it could carry. Unlike Russia in the early 1990s, Chinese pilots are already capable of making night landings. China should be able to deploy the Liaoning in one or two years' time, as Russia did in the Mediterranean in 1996. ${ }^{(37)}$

With China's new strategic submarines base in Hainan, safeguarding the patrol areas of the SSBNs may correspond to a Soviet-inspired "naval bastion strategy" (haijun lengbao zhanlüe 海军棱堡战略) where the carrier would sanitise an area and create the conditions for a credible second strike capability by warding off foreign submarines, ships, and aircraft. ${ }^{(38)}$ Latest estimates on China's new JL-2 strategic missile give a range of 7,500 km, which is sufficient to strike Alaska and Hawaii from defended sanctuaries in China's Bohai Sea. It is unlikely that Chinese SSBNs could escape undetected to the Kuril Islands area, from which they could strike most of the continental United States. ${ }^{39}$

\section{How many carriers?}

On 31 December 2015, China's Defence Ministry confirmed the construction of China's first home-built aircraft carrier, the Type 001A. Captain Zhang Junshe explained that China is building its second aircraft carrier "completely on its own" at the Dalian shipyard in northeastern Liaoning Province. The acknowledgement came more than one year after the governor of Liaoning Province, a former shipbuilding executive, gave a speech to the shipyard's workers about the new task they faced. Zhang praised the experience gained during the Liaoning's sea trials to help the designers in their work, confirming implicitly that the Type 001A will be a replica. ${ }^{(40)}$ Asked how many carriers China would need, Zhang Junshe cited India's three and responded that "a country like China theoretically needs at least three aircraft carriers to ensure that one is always in operation." (41) He urged "China threat proponents" to consider the country's population, superficies, coastline, and maritime territory. ${ }^{\left({ }^{42}\right)}$ Asked about the prerequisites for building an aircraft carrier, Zhang Junshe explained that it demanded mature shipbuilding, aeronautical, electronic, communications, and logistics industries. Asked about the time needed, he cited the American example of about three years for building the ship, two years for installing weapons and equipment, and one year to familiarise military personnel, adding that there was no schedule for China, since it did not have the American experience. ${ }^{(43)}$ Asked about the role of the future carrier, he stressed that the Liaoning would remain a training platform while the new carrier would be a fighting unit. ${ }^{(44)}$ Asked to evaluate China's ranking in relation to the rest of the world's navies, Zhang Junshe responded that it was too early "to say when China will become a global naval power." (45)

Chinese commentators also addressed the third aircraft carrier (Type 002). Zhang Junshe explained that China is not yet ready for a nuclear-powered platform, given the safety issues and the need to refuel the reactor after 15 years. ${ }^{(46)}$ Other commentators argue that the carrier program is a gradual process and that China cannot aim immediately at duplicating an American
Ford class aircraft carrier despite several artist's renderings that represent a 100,000-ton US-inspired aircraft carrier, departing completely from the Soviet legacy of the Liaoning and Type 001A. ${ }^{(47)}$ In the meantime, China may build a Type 002, along the lines of Type 001A but with catapults instead of a ski-jump. With three carriers by 2030 , not counting the Liaoning, China could contemplate forcing Taiwan into submission and delaying or deterring the US Pacific fleet.

Regarding the rumoured Type 081 "through deck helicopter carrier amphibious assault ship," author Shi Bin acknowledges the advantages of an amphibious assault ship and discusses whether China's current Type 071 multi-functional dock landing ship could evolve gradually into an indigenous amphibious assault ship: "An amphibious assault ship provided with comprehensive and oceanic combat capabilities would bring good benefits, especially for its large-scale aviation facilities [to perform] multi-role anti-submarine and mine clearance [missions]." Shi Bin sees the advantage of vertical landings for the PLA Marines but notes that the main obstacle would be the aviation industry's inability to provide an appropriately sized helicopter. Shi Bin underlines that the "development of the Chinese Navy's amphibious ships must reflect the ideological perspective of an overall [Chinese] defensive strategy, very different from the US global strategy." Furthermore, he stresses its costs: "The amphibious assault ship also has high acquisition and maintenance costs (...) while China's economic conditions do not allow for large-scale equipment and for an amphibious assault ship military strategy." However, in the longer term, Shi Bin considers the procurement of amphibious assault ships by China as "inevitable" (shi biran de 是必然的) both to solve the Taiwan issue and as a "necessary tool" to project national power and improve China's international influence at a lesser cost than the deployment of an aircraft carrier. ${ }^{(48)}$

Is the carrier the ultimate weapon? An article published in Guofang cankao (National Defense Reference) and posted on the website Zhongguo junwang ${ }^{(49)}$ stresses that the future of the aircraft carrier is uncertain: how long

36. Mathieu Duchâtel, François Godement, Alexandre Sheldon-Duplaix, "China's Sea Power, Reaching Out to the Blue Waters," China Analysis, The European Council on Foreign Relations, March 2011.

37. Alexandre Sheldon-Duplaix, "Chinese Aircraft Carriers: They're Already on the Way," art. cit.

38. "Zhongguo waliang gehao zhandou hangmu yao jiameng Nanhai jiandui da xiaochou" (China Kuznetsov-class aircraft carrier should reinforce the Southern Fleet to fight the clowns), Yadong Junshiwang, 18 May 2010, www.warchina.com/news/ent/2010-05-18/121550.html (accessed on 20 January 2016); "Beihai jiandui yi hangmu peizhi zhenshe Yuenan qijian jiangnei dingwei Waliangge" (Aircraft-carrier Varyag will become flagship of the North Sea Fleet and deter Vietnam), MilChina, 25 April 2010, www.milchina.com/2010/0425/430.htm (accessed on 20 January 2016).

39. Ronald O'Rourke, China Naval Modernization: Implications for U.S. Navy Capabilities - Background and Issues for Congress, op. cit., p. 18.

40. "Need for Second Aircraft Carrier is Real," China Daily Europe, 8 January 2016.

41. India has only two aircraft carriers currently in service but hopes to procure two more carriers for a total of three, one being built as a replacement; Stephen Saunders, Jane's Fighting Ships 201516, op. cit., pp. 333-336.

42. "Need for Second Aircraft Carrier is Real," art. cit.

43. Ibid.

44. Ibid.

45. Ibid.

46. Ibid.

47. "Junmei pu Zhongguo haijun liang da ding liang zhu hangmu zhi shi qiyi" (Army media exposure of the Chinese Navy aircraft carrier is just one of the two pillars), Menglianwang (fovvp.com news), 20 January 2016, www.fovvp.com/news/2016/01/20/942.html (accessed on 25 January 2016).

48. Shi Bin, "Qianxi woguo liang qi jian ting weilai de fazhan" (Working on the future development of amphibious ships), Sohu shequ, 1 September 2015, http://club.mil.news.sohu.com/shilin/ thread/3gcbtt28vdu (accessed on 30 January 2016).

49. Li jie, "Cong Meiguo hangmu fazhan kan Zhongguo hangmu weilai zouxiang" (Observing the future of China's aircraft carriers from the development of US aircraft carriers), Guofang cankao, 18 January 2016, www.81.cn/jskj/2016-01/18/content_6861559.htm (accessed on 30 January 2016). 
will the aircraft carrier be able to "dominate" the oceans? When will other countries "change course" in "the development of other advanced warships or new concept weapons"? The US Navy is developing "new concept" weapons such as the $300 \mathrm{~km}$ electromagnetic railgun and the tactical laser. However, the authors take note that the US Navy still trusts the aircraft carrier to ensure "sea supremacy" (haishang bazhu 海上霸主) until the end of the century. The future Ford class should be more powerful than the Nimitz: the number of daily sorties should increase from 140-160 to 180220. The carrier is also characterised by its global role, both for displays of strength during crises and for "soft power," as demonstrated by the United States during the 2004 Indian Ocean Tsunami and the 2010 earthquake in Haiti. (50)

\section{New missions}

For more than a decade, Chinese experts have been writing extensively on the question of "sea power." They tend to agree that protecting China's growing global interests requires both naval modernisation and economic development, and that the country needs an ocean-going "blue-water" fleet (lan shui 蓝水). Until about 2008, they did not view the protection of the SLOCs as a main driver for China's maritime strategy. ${ }^{(51)}$ Chen argued that the idea of protecting the SLOCs had no significant influence on China's national security strategy (zhipeixing zuoyong 支配性作用). Chen and other Chinese experts explained that "protecting maritime interests" (baohu haiyang quanyi 保护海洋权益) was becoming increasingly important while the defence of Chinese sovereignty in neighbouring waters remained the core mission. ${ }^{(52)}$

Many view the 21 antipiracy patrols conducted in the Gulf of Aden since 2008 as a turning point, with the beginning of a permanent Chinese naval presence in the Indian Ocean alongside Mahanian principles to safeguard the SLOCs. ${ }^{(53)}$ Chinese analysts confirm this view. For Cao Weidong, China's naval strategy shifted from brown to blue waters, following the earlierWestern examples of Britain and the United States. As Cao observes, China is espousing the theories of Mahan and Corbett maximising the interests of the country through the sea. The "21st Century Maritime Silk Road" is an initiative unveiled by Chinese President Xi Jinping in October 2013 to connect China with Asia, Africa, and Europe. It aims to promote trade cooperation and cultural exchanges among the peoples, paralleling the land Silk Road across Eurasia. Cao Weidong sees the 21 escort task forces deployed to the Gulf of Aden since December 2008 as a major step towards the Navy's new role of safeguarding the "Maritime Silk Road," stressing the importance of cooperation with other navies to fulfil this mission. ${ }^{(54)}$ The "Maritime Silk Road" has been allocated almost $\$ 50$ billion for "win-win" projects with neighbouring countries. For Cao Weidong, China's "deep sea power strategy is imperative." And it must overcome continental inertia and US-Japan containment. ${ }^{(55)}$

China's 2010 White Book emphasised both the defensive and deterrent role of the "offshore defense strategy" beyond the first island chain and referred to operations in distant waters: "In line with the requirements of offshore defense strategy, the PLA Navy (PLAN) endeavors to accelerate the modernization of its integrated combat forces, enhances its capabilities in strategic deterrence and counterattack, and develops its capabilities in conducting operations in distant waters and in countering non-traditional security threats." The paper refers to "new method of logistic supports for sustaining long-time maritime missions" and "on drills in distant waters" for "missions other than war." (56) China's 2015 White Paper slightly changes the wording to incorporate "open seas protection":

In line with the strategic requirement of offshore waters defense and open seas protection, the PLA Navy (PLAN) will gradually shift its focus from "offshore waters defense" to the combination of "offshore waters defense" with "open seas protection," and build a combined, multi-functional and efficient marine combat force structure. The PLAN will enhance its capabilities for strategic deterrence and counterattack, maritime maneuvers, joint operations at sea, comprehensive defense and comprehensive support. (57)

Departing drastically from the original air defence justification beyond the first island chain and in the South China Sea, writers now link the aircraft carrier to "China's foreign trade": "China's economy is increasingly dependent on the 'maritime lifeline'." For the China Ocean Shipping Company $(\mathrm{COSCO})$ routes and the " $21^{\text {st }}$ Century Maritime Silk Road's protection" commentators argue for "a strong fighting force" (zhan li qiangda 战力强大) with "both offensive and defensive naval forces" (gongfang jian ju di haishang liliang 攻防兼具的海上力量). Therefore, "China's homeland defense strategy must protect national interests in all areas and regions from a defense strategy perspective." The development of a "blue water" (lan shui) navy is presented as a first step for China's sea power strategy to address the energy security problem and reduce a situation of vulnerability. ${ }^{(58)}$ Reporting on the commissioning of the Liaoning in September 2012, China Daily referred to China's interests on the high seas as "the world's largest exporter in 2009," with "63 percent of its iron ore and 55 percent of its crude oil imported by sea in 2010" and linked the aircraftcarrier to China's economy as a guarantor of "the safety of China's personnel, assets, and shipping lanes." (59) The paper also linked the rebuilding of the Varyag to China's increasing global status and responsibilities under the United Nations, citing peace-keeping missions, counter-piracy patrols, and humanitarian assistance. For mainstream media circulating official or near-official views such as China Daily or Feiyangwang, the creation of a Chinese aircraft carrier battle group meant to protect China's economic lifeline from the South China Sea to the Strait of Malacca and the Indian Ocean has become a priority.

Would China deploy its aircraft carrier to influence events ashore? In October 2015, with the Liaoning still conducting sea trials with barely 10 fighters available, the Lebanese and Israeli press speculated that the Chinese

50. Ibid

51. Mathieu Duchâtel, François Godement, Alexandre Sheldon-Duplaix, "China's Sea Power, Reaching Out to the Blue Waters," art. cit.

52. Ibid.

53. James Holmes, Toshi Yoshihara, China's Naval Strategy in the 21st Century: The Turn to Mahan, London, Routledge, 2009; see also, James Holmes, Toshi Yoshihara, "A Chinese Turn to Mahan?", China Brief, Vol. 9, No. 13, 24 June 2009.

54. "Cao Weidong: Zhongguo haijun zhanlüe bianhua; cong huangshui zou xiang lanshui" (Cao Weidong: Chinese naval strategy: Change from brown to blue water), art. cit.

55. Ibid.

56. "Full Text: China's National Defense in 2010," Xinhuanet, 31 March 2011, http://news. xinhuanet.com/english2010/china/2011-03/31/c_13806851.htm (accessed on 30 January 2016).

57. The State Council Information Office of the People's Republic of China, "China's Military Strategy," art. cit. (Part IV).

58. "Junqing guancha: haiquan zhanlüe cuisheng Zhongguo hangkong mujian (zutu)" (Military observation: The birth of the Chinese aircraft carrier sea power strategy [Photos]), art. cit.

59. "Navy Sails into New Era," China Daily, 26 September 2012, www.chinadaily.com.cn/china/201209/26/content 15782885.htm (accessed on 30 January 2016). 
carrier was heading for Syria to participate in air strikes alongside the Russian air force. In an interview with the Chinese newspaper Huanqiu shibao (Global Times), Captain Zhang Junshe rejected "false rumours" about the Liaoning being "en route" to the Mediterranean. While not dismissing the idea that China could deploy an aircraft carrier during an international crisis, Zhang reiterated Beijing's longstanding position that it should not interfere in another country's internal affairs: "China's position is to respect the free choice of the Syrian people and not to add to a military intervention in Syria or a forcible power shift, which is why China could not send an aircraft carrier to Syria to interfere in the internal affairs of the country." (60)

Another method to influence events ashore is to provide relief to developing countries. Researchers from the Department of Political Science of the Dalian Naval Academy (61) bring a new justification for China's hospital ship An Wei, commissioned in 2006 to support a military operation against Taiwan. Liu Hui and Liu Jiefeng from the Wuhan Naval University of Engineering stress the need to develop military soft power in Military Operations Other Than War (MOOTW) to augment China's influence in the world and before the world's opinion. The An Wei inaugurated this new kind of naval diplomacy under the concept of the "harmonious ocean philosophy." Codenamed "Mission-Harmony," the hospital ship's five deployments to the Indian Ocean, the Philippines, and Latin America are described as "an ideological weapon for shaping a favourable environment for the PLAN." (62)

\section{Does the "21st Century Maritime Silk Road" constitute a "string of pearls"?}

Since 2005, American, Japanese, and Indian researchers have anticipated the construction of a network of Chinese naval bases that would enable China to encircle India and project its naval forces into the Indian Ocean. Those analysts have long argued that China is seeking to build a "string of pearls" by investing in harbour installations in Pakistan, Bangladesh, Sri Lanka, and Myanmar. ${ }^{(63)}$ Hideaki Kaneda, a retired Japanese admiral, observed that the Chinese were constructing strategic relationships and sea ports along the sea lines stretching from the South China Sea to the Persian Gulf (Gwadar in Pakistan, Sittwe, Kyaukpu in Burma, Hambantota in Sri Lanka). Under Mahanian logic, this "string of pearls" would permit largerscale military deployments in the future to protect Chinese commerce: "All of Asia must wake up to the arrival of Chinese-style aggressive 'Sea Power.' Japan, in particular, must reformulate its national maritime strategy with this in mind." (64) Accordingly, since 2006, Japan's Defense White Book sees a fourth mission for the Chinese naval forces: "to defend Chinese sea lanes, probably beyond Chinese home waters." (65)

For a long time, China ruled out the possibility of acquiring naval bases abroad, denying that Gwadar could become a naval base despite Pakistan's desire that China should think otherwise. China has relentlessly rejected this interpretation, explaining that its investments in foreign ports is market driven. In September 2012, Captain Zhang Junshe explicitly dismissed the "string of pearls" theory, blaming Western scholars "who see the development of China's aircraft carrier and missiles as a threat to other countries" and "allege that China is building a series of military bases, or the so-called string of pearls, in the Indian Ocean under the pretense of helping some countries build commercial port facilities." (66) Zhou Bo of the Chinese Academy of military science clearly refuted the "string of pearls" concept and denied the report that China is planning to build military bases around the Indian Ocean. He wrote:
"China has only two objectives in the Indian Ocean: economic benefit and the security of shipping lines." (67)

With the mainstream concept that China's blue water navy and its aircraft carriers will protect the new " $21^{\text {st }}$ Century Maritime Silk Road" initiative, Phoenix TV published an interesting analysis of the mutually supporting land and maritime Silk Roads in relation to the Taliban resurgence in Afghanistan and its threat to the Pakistani government and consequently to Gwadar as the future main port of Western China. Gao Bai, director of the Center for Strategic Studies of Chinese High-speed Rail of Southwest Jiaotong University, and professor at Duke University, addresses the strategic significance of Pakistan for China's sea power and its railway from Gwadar (on the Indian Ocean) to Kashgar. ${ }^{(68)}$ With its government losing control of the Islamic groups that used to fight India in Kashmir, and with an energy deficit that drives investment abroad, Pakistan is highly vulnerable, causing a security threat on China's borders and in Xinjiang Province. Furthermore, Afghanistan might once again fall into Taliban hands. To overturn the situation, the researchers believe that China must invest heavily in Pakistan and more specifically in the construction of the Pakistani port of Gwadar and in the China-Kashgar Railway. Accordingly, "if the China-Pakistan's economy becomes highly integrated, the port of Gwadar could be turned into China's western port, comparable to Shanghai or Ningbo." Gao Bai further explains that "if you build a powerful navy base in Gwadar, China can give an effective and timely response to any threat to China's interests emerging from the Middle East." For Gao Bai, a military base in Gwadar would greatly increase confidence and cooperation with China's economic partners in the region Sri Lanka, Bangladesh, Myanmar - and facilitate the emergence of a "string of pearls," the very concept that American, Japanese, and Indian researchers fearfully anticipated two decades ago. He stresses that such a strategic move would facilitate China's control over Xinjiang separatists and secure its western borders while making China a genuine Indian Ocean country and safeguarding national sea power. By endorsing Pakistan's security interests, China would rein in terrorism, not only in Pakistan but also in Afghanistan. Regarding India's opposition to China's naval ventures in the region, the authors feel that China should first "establish its presence in the Indian Ocean, and then look for cooperation on the basis of peaceful coexistence with India." With China acting as a stabiliser, Gao Bai sees a strategic interest for India to seek better relations with Pakistan in order to use the Pakistani railway to export its goods to Iran, Turkey, and Europe, as well as Central Asia. Instead

60. Quoted by Sputnik, "Expert Shatters Rumors About Chinese Aircraft Carrier in Syria," 28 September 2015, http://sputniknews.com/world/20150928/1027641739/china-syria-aircraft-carrier-rumors.html (accessed on 30 January 2016).

61. Chi Zhiyan, Shao Ren, and Shi Jiazhu.

62. Liu Hui, Liu Jiefeng, "Tigao guoji yulun yingxiang li tuijin wojun 'ruanshili' jianshe" (Enhancing the world opinion influence to develop military soft power), Haijun gongcheng daxue xuebao (zonghe ban) (Journal of Naval Engineering [Comprehensive Edition]), No. 4, 2011, pp. 13-16.

63. Christopher J. Pherson, "String of Pearls: Meeting the Challenge of China's Rising Power across the Asian Littoral," Strategic Studies Institute, June 2006.

64. Hideaki Kaneda, "The Rise of Chinese 'Sea Power'," Project Syndicate, 8 September 2005, www.project-syndicate.org/commentary/kaneda7/English (accessed on 30 September 2010).

65. MOD of Japan, Defense of Japan 2006 (Annual white paper), p. 49.

66. Wang Xiaoxuan, "Strong Navy Protects Interests," art. cit.

67. "Rimei 'haishang sichou zhi lu' shi Zhongguo zhengming zhi ju (Japanese media: "Maritime Silk Road" is a name replacement by China), Chinanews, 14 February 2014, www.chinanews.com/ gj/2014/02-14/5839943.shtml (accessed on 25 August 2016).

68. Gao Bai, "Zhong Ba tielu you he zhongda zhanlüe yiyi: zhu Zhongguo dianding lu quan zhan lüe," (What is the Pakistan Railways' strategic significance to help China lay a land rights strategy?), Feiyangwang, 26 January 2016, http://m.fei123.com/1250000/1249170.shtml (accessed on 30 January 2016). 
of antagonising India, the authors believe that "this strategy will greatly change the current situation of mutually suspicious Sino-Indian relations to create the conditions for common Sino-Indian strategic interests. Ultimately, the authors would hope to extend this land route and railway connection to the Arabian Peninsula and the African continent. (69)

\section{How to handle the United States?}

Notwithstanding Captain Zhang Junshe's reassuring remarks, a worrying note still exists. It suggests that China's build-up is destined to change the military balance and facilitate the use of force in sovereignty disputes, stating that "the time to use force, recover the occupied territories, and safeguard maritime rights and interest is gradually approaching." The same source suggests that "China cannot shelve the dispute hanging over its joint development principle by making enormous concessions." (70) Japan and its American ally are also seen as the most formidable opponents interfering in China's sovereignty issues over Taiwan and the South China Sea: ${ }^{(71)}$ Japanese Prime Minister Abe has an interest in maintaining a tense relationship with China to push forward his "constitutional amendment" campaign, and disregarding Chinese and Korean feelings, the Japanese Prime Minister's visits to the Yasukuni Shrine have exacerbated tensions since December 2013. According to this view, the United States and Japan have also taken advantage of the crisis: "[Their] efforts to counter China's new maritime strategy are clear," and the land reclamation by China in the South China Sea is being used by the United States as a pretext for its naval presence in the area, while China's new blue water strategy is being used by the Abe cabinet in his efforts to "normalise" the military in Japan. ${ }^{(72)}$ In sum, the new version of "Japan-US defence cooperation guidelines" has ensured closer relations between the two allies to contain China's maritime developments over "three seas interaction" (sanhai liandong 三海联动) that would conveniently unite the East and South China Sea dispute with the Taiwan issue. However, a reassuring note concedes that all parties have shown an interest in establishing crisis management and control mechanisms to prevent the accidental outbreak of war, and that the United States, Japan, and the Philippines are seeking confrontation but not war. This policy is portrayed as the "fight but avoid war" (yao douzheng dan ye yao bi zhan 要斗争但也 要避战) principle. ${ }^{(73)}$

The Global Times and Xinhua editorialist Zhou Xiaoping claim that the United States Navy's is ten times superior to its closest foe, with Washington controlling $80 \%$ of the global trade through its more than 200 military bases. Zhou explains that the United States - following the British example - leads the world, not for a "better system" but because sea power gives it control of the world's routes and markets. Zhou Xiaoping compares the United States to the Ottoman Empire: two "bad systems with a strong military power to dominate the trade routes." He explains that US maritime domination puts pressure on China's maritime routes, just as the Ottoman Empire put pressure on China to dominate the Silk Road. The author believes that Chinese "clean" fast trains will bring tremendous geopolitical and geo-economical changes to Eurasia and the World, putting an end to Anglo-Saxon domination. He calls the "China high-speed rail strategy a deadly challenge to NATO-led naval power." With its new high-speed rail network, Chinese railways advocates hope that China's new high-speed rail network will connect Chengdu, Istanbul, and Hamburg in just 16 and 18 hours. Pushing the argument to the extreme, some railways lobbyists argue that intercontinental land transportation will replace sea transportation and bring wealth and political stability to Eurasia. ${ }^{(74)}$ Accordingly, they believe that land rights issues will matter more than maritime rights issues in the future. ${ }^{(75)}$

An anonymous author in the military section of the Sina website, which can be regarded as mainstream, notes that "with the implementation of the 'United States' return to Asia-Pacific strategy'," the People's Navy faces "a real and urgent anti-submarine warfare challenge." He remarks that the American "Virginia-class submarines commissioned recently are quieter and well-armed with 1,600-2,500 km Tomahawk cruise missiles [that constitute a major threat] to the economic, military, and industrial heart of the coastal urban areas (including Beijing)." The editor explains that China has made great progress "on the road to developing conventional submarines for offshore operations" with the types 039A and 039B Yuan class Air Independent Propulsion (AIP) submarines. The author lists four key technologies for conventional submarines that China must improve: Air Independent Propulsion, towed array sonar technology, $\mathrm{X}$ shaped rudders, and "vibration damping technology." (76)

In July 2014, Modern Ships (xiandai jian chuan 现代舰船) a popular magazine, translated an article by Walter McDougal on "American Grand Strategy: From History to Present." The editor explored scenarios for "power sharing" between the US and China under various mechanisms such as a "cooperative equilibrium" (hezuo xing pingheng 合作性平衡), a "grand bargain" (da maoyi 大贸易), or a "big compromise" (da tuoxie 大妥协). Washington would have to give away its lead in exchange for cooperation with China. The Modern Ships' reviewer understood the confrontation between the US and China as a manifestation of Huntington's clash of civilisations and as a consequence of American self-confidence (Meiguo shi zixin 美国 式自信) despite a declining economy. The commentator saw the United States as an "arrogant leader" that "is not serious about the possibility of sharing power." (77)

The PLAN is more open in its relations with the United States. In November 2012, Navy secretary Ray Mabus was given a tour of a brand new Yuan-class AIP submarine while a delegation of 29 US Navy Captains visited the Liaoning in October 2015. As noted by Global Times, 2015 was the first year in which the two sides exchanged delegations at such a high level to discuss operations, communications, and the Code for Unplanned Encounters at Sea

69. Ibid

70. "Zhongguo haiquan zhanlüe da zhuanbian zouxiang shiji" (Chinese sea power strategy great change becomes reality), Feiyangwang, 26 January 2016, http://m.fei123.com/1250000/ 1249139.html (accessed on 30 January 2016).

71. "MeiRi dengzhen dui Zhongguo de haiyang zhanlüe rijian qingxi!" (It is increasingly clear that the United States and Japan are countering China's maritime strategy!), Feiyangwang, 26 January 2016, http://m.fei123.com/1250000/1249181.html (accessed on 30 January 2016).

72. Ibid

73. Ibid.

74. "Zhongguo gaotie zhanlüe jiang dui Beiyue wei shou de haiquan guojia xingcheng zhiming tiaozhan" (Chinese high-speed rail strategy will be a deadly challenge to NATO-led naval power), Feiyangwang, 26 January 2016, http://m.fei123.com/1250000/1249143.shtml (accessed on 30 January 2016). It is important to note here that some observers contest this Chinese view, especially with regards to China's imports of energy and other bulk commodities. They argue that the geographical location of source countries for raw resources and the favourable economics of shipping make the replacement of the seaborne resource trade highly unlikely.

75. Ibid.

76. Xinlang junshi bianzhe (Sina Military Editor), "Shendu: qianxi Zhongguo weilai changgui qianting fazhan de si da guanjian jishu" (Depth: Four key technologies for China's future development of conventional submarines), Sina, 27 March 2014, http://mil.news.sina.com.cn/2014-0327/1601771012.html (accessed on 30 January 2016).

77. "Meiguo da zhanlüe yu haiquan: zui da wangpai shi zhanlüe zongshen he shengchanli" (American grand strategy and sea power: Biggest trump cards are strategic depth and productivity), Xiandai jianchuan (Modern ships), available at Fenghuang zixun, 23 July 2014, http://inews.ifeng.com/yidian/41276381/news.shtml?ch=ref_zbs_ydzx_news (accessed on 30 January 2016). 
(CUES), an agreement reached at the 2014 Western Pacific Naval Symposium to reduce the chance of an incident at sea between the major regional navies and the United States. The hawkish Global Times approved, stating that "China and the US should establish regular exchanges regarding military equipment, technology and strategies to shape a comprehensive and multidimensional image of each other." (78) Officially, the Chinese Navy sees "freedom of navigation operations" (FONOPS) by the US Navy near the disputed islets and reefs in the South China Sea as "the latest attempt by Washington to return tension to the South China Sea and encourage more regional stakeholders to challenge China." Foreign Ministry spokeswoman Hua Chunying said that under the Chinese Law on the Territorial Sea enacted in 1992, foreign warships entering China's territorial sea must obtain approval from the Chinese government. Captain Zhang Junshe, the aforementioned naval analyst, explained that one of the US goals is "to bring tension back to the region." "In the long run, Washington still defines the South China Sea issue as a tool to contain China," Zhang Junshe added. ${ }^{(79)}$

However, a senior Chinese researcher noted that the United States had waited for the month of November to conduct their first FONOPS while at the same time the US and Chinese navies joined for an exercise in the Atlantic and Admiral Wu Shengli communicated through a video conference with US officials. He added that the main accomplishment of President Xi's visit to the United States was a commitment from both countries not to engage in a new Cold War. ${ }^{\left({ }^{80}\right)}$ Another senior researcher was less positive, mentioning the risk of incidents and the impact on common Chinese people who resent when their government reacts too weakly to the US naval presence on China's shores. ${ }^{(81)}$

Che Yue, a member of the Naval History Research Association, suggests acting with caution so as not to provoke the United States: "If we continue to develop overseas interests, including in Africa, if we continue to expand trade cooperation with Europe, while we follow the right strategy, China is likely to become a maritime country. But this strategy requires very careful thinking. China's rise will have inevitably led to confrontational relations with the United States, the Pacific's other major country." In order to prevent conflict, Che Yue suggests that "China's Sea Power development [should] follow the wartime American model" and not Germany's model. Before World War I, Berlin challenged Britain in the North Sea while the United States abstained from provoking Britain. And after the end of World War I, the United States Navy secured parity from the Royal Navy at the 1922 Washington Treaty after having promoted the concepts of "equality and cooperation." Even so, Che Yue notes that the United States might have fought Britain under "War Plan Red" if London had threatened its sphere of influence in the Caribbean. ${ }^{(82)}$

The emergence of a Chinese maritime power brings together a tacit alliance between India, Vietnam, Japan, and Australia, the latter two being already the closest American allies in the region.

\section{Conclusion}

China has embarked on a build-up aimed at making China a "sea power" mainly in the Indo-Pacific region to deter US intervention in Taiwan and to protect its trade in the Indian Ocean. China has acquired a mediumsized aircraft carrier about one tenth as capable as a US super-carrier and is learning the ropes as fast as the more experienced and poorer Russia did in the early 1990s. As a source of pride for its citizens, China's aircraft carrier program plays into the hands of the Communist Party to demon- strate its legitimacy and success. Within two to three years, China will be able to deploy its first carrier with a dozen or more fighters just as Russia did in 1996. Like the former Soviet Union, China is building a second and planning for a third and a fourth carrier, the last most likely larger and nuclear. And yet, China's first two medium-sized aircraft carriers are much less capable than the United States' ten super carriers and ten amphibious assault ships with vertical-short take-off and landing aircraft. If it limits the number of its future aircraft carriers to three or four units, China will remain a regional navy with global reach leading India, the UK, and France at that level.

China is securing its first military base abroad. So far, this development cannot compare with the US and Western military presence across the world, and Chinese commentators can rightly feel offended by the outcry. A real changing factor would be the creation of a naval base in Pakistan. So far, China appears to be more interested in the geo-economic effect of the Gwadar-Kashgar corridor on its western provinces. And it is trying to win India's support for this project by opening markets to its longstanding adversary. In that context, it is unlikely that China will seek to confront the Indian Navy in the Indian Ocean as many anticipate, although it should increase its surveillance of India's strategic submarines in the Gulf of Bengal by deploying more submarines to this area, most likely from Hainan and not Gwadar.

In the past fifteen years, the PLAN has developed credible air defence and anti-submarine capabilities on its modern ocean-going combatants for operations beyond the Western Pacific first island chain. Although it certainly lacks the anti-submarine experience of Western navies - partly lost in the aftermath of the Cold War - the PLAN is no longer innocent in the field. At the same time, China still lacks the "large number of nuclear attack submarines" that would allow the country to gain sea control in distant areas or to replicate the Soviet Union's challenge to the United States carrier battle groups. Given economic, technical, and industrial constraints, China will not field more than 12 newer nuclear attack submarines in 2025. By then, its combat capabilities will remain at least ten times inferior to those of the Soviet Navy at its best. In particular, China does not have supersonic long-range bombers or anti-submarine long-range aircraft to conduct offensive maritime operations at a very long distance. Can its long-range antiship ballistic missiles play that role? Could it be a game-changer as some Western analysts have claimed? So far it only appears to be a factor in a Taiwan contingency. It might keep US aircraft carriers from crossing the first island chain towards China, reducing the reach and effectiveness of their strikes. Those missiles have a better probability of hitting a carrier sailing through choke points where targets could be more easily detected and where missiles could be programmed with fixed parameters. Will it affect the United States' implicit commitment to defending Taiwan's freedom? This remains to be seen.

Through military modernisation, China has already achieved the political objective of making Taiwan's de jure independence impossible. If there is a

78. Li Ruohan, "A US Navy Delegation of 27 Naval Captains Boarded the Aircraft Carrier Liaoning on Monday," Global Times, 21 October 2015.

79. Dong Zhaohui, "US Warship's Incursion Aims to Renew Tension," China Daily, 2 January 2016

80. Interview with a senior researcher, Beijing, 8 December 2015.

81. Interview with a senior researcher, Shanghai, 5 December 2015.

82. "Chen Yue tan haiquan: Zhongguo fazhan haiquan: kecan zhaoyi zhanshi Meiguo moshi" (Chen Yue on Sea Power: China Sea Power Development can refer to a wartime American model), Feiyangwang, 26 January 2016, http://m.fei123.com/1250000/1249268.shtml (accessed on 30 January 2016). 
"China threat," it is mostly against the "province" of Taiwan, China's new navy being trained to deter or keep at bay a US intervention while contributing to securing a rapid victory on the island. As long as China claims to respect the 2002 Declaration on the Conduct of Parties in South China Sea, the PLAN's modernisation only appears as an intimidating factor for smaller nations such Vietnam and to a lesser extent Malaysia, which all have sovereignty issues with China, although it could be argued that the toothless Philippines, backed up by the United States and Japan, remains immune to intimidation. In the East China Sea, China has resurrected a long-shelved maritime dispute with its former partner against the Soviet Union to protest Japan's celebration of its war heroes with repeated official visits to the Ya- sukuni Shrine. In that context, the Code for Unplanned Encounters at Sea (CUES) adopted by the major navies in 2014 greatly reduces the risk of unwanted confrontation.

Alexandre Sheldon-Duplaix is researcher and lecturer at the French Defence Historical Service.

Service historique de la Défense, Château de Vincennes, Avenue de Paris, F - 94306 Vincennes Cedex, France

(asheldonduplaix@hotmail.com).

Manuscript received on 7 April 2016. Accepted on 21 July 2016. 